しても, 骨導聴力に関する研究委員会を早急に進めて ゆく必要を痛感する。

断続器操作時のクリックは, 6 名の人がきいて 5 名 以上きこえないことといら規定について問題が残る。 人間にはあまり恒常性がない。メーカー側できこえな いと判断したものが，規格を検査した人にきこえる場 合どうなるであるう。このクリックは難かし、問題で あるが，物理的にクリックの出ない条件というものが わかっているらしいから，たとえそれが不完全であっ ても, といらのは, 物理的には出ない筈でもクリック として感ずることがあるからであるう。しかし物理的 にクリックの出る範囲は少くとも抑えられる，この点 に関しその条件を規格として入れるこどを主張した が，反対にあって実現しなかった。IEC規格では断続 器の立上り時閒は物理的に規定されている。悪く解釈 すると, 製作に都合の良い部分だけは取り入れるが, たとえそれが正しくても製作に面倒な処は規格に入れ ないかの如く思われる。それにつけても残念なのは使 用者側の意見の不統一である。全員が結束していな い。要するに勉強不足といらか, 製作者側に押された 感が強い。もう少し熱意を以て規格改訂に望むべきで あった。これは私の感じた処である。

$$
\text { オージオメータＩIST } 1201
$$

1. 総 則

1.1 適用範囲 この規格は医科において純音を用 いて個人の聴力を測定するオージオメータについて規 定する。

\section{2 用語の意味}

(1) 気導 気導とは音波が外耳道の中の空気を通し て内耳へ伝へられることをいら。

(2) 骨導 骨導とは音波が頭蓋骨を通して内耳へ伝 えられることをいう。

（3）最小可聴值 最小可聴値とはきこえるといら感 覚を起す音圧の最小值で実効值で表わされる。純音で はその周波数により異なる。また人によって,この值 は異なるし, 同じ耳でも, それを聞かせる方法, 音圧 を測定する場所によって異なる。
（4）基準の最小可聴値 基準の最小可聴值とは，正 常な耳の最小可聴值として定める值である。その值を 規定のカップラ (4.2 図6参照) に気導受話器を結合 したときその内部に発生する音圧で示すと表 1 のよう になる。

(5) 聴力損失 聴力損失とは周波数について，その 最小可聴值と基準の最小可聴値との比をデシベルで表 わしたものをいう。

(6) マスキング マスキングとは，ある音に対する 最小可聴值が他の音の存在によって大きくなる現象を いう。測定する耳に与えた純音が測定しない側の耳に 聞こえるのを防止するためにその耳にマスキング用雑 音を聞かせる場合がある。

1.3 種類 オージオメータは使用目的により診断 用および選別用オージオメータに分け，さらにおのお のは主として純音の周波数および聴力損失の測定範围 によってI形と II 形とに分ける。

\section{2. 構 造}

2.1 構成 オージオメータは電気的純音の発生装 置であって, 診断用は正弦波発生器と純音の減衰器, 断続器, 気導受話器, 骨導受話器, マスキング用雑音 発生器と雑音の減衰器, 受話器および被検者の応答表 示器などからなり, また選別用は正弦波発生器と純音 の減衰器,断継器および気導受話器などからなり、いず れも一体に構成されているものとする。気導受話器を 2つ備えるものにあっては同時に使用するときにもそ れぞれの出力がこの規格に適合しなければならない。

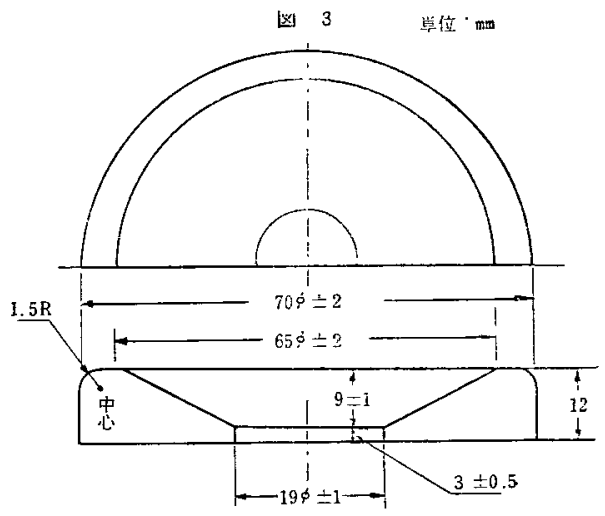

表 1

\begin{tabular}{|c|c|c|c|c|c|c|c|c|c|c|c|}
\hline 周 波 数 $\mathrm{c} / \mathrm{s}$ & 125 & 250 & 500 & $(800)$ & 1,000 & $(1,500)$ & 2,000 & $(3,000)$ & 4,000 & $(6,000)$ & 8,000 \\
\hline 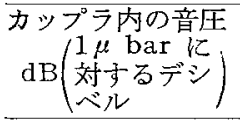 & -20 & -34 & -49 & -55 & -57 & 57 & - & 58 & - & -56 & - \\
\hline
\end{tabular}


2.2 気導受話器および骨導受話器 気導受話器お よび骨導受話器は長年にわたって安定な動作を保持す るような構造でなければならない。

気導受話器の耳当の形状, 寸法は図 3 によるものと する。その材質は人体に無害なスポンジゴムまたはこ れと同等以上の性質をもつものとし，適当な消毒に耐 えるものであること。

2.3 純音の周波数 オージオメータ㹥その発生す る純音の周波数をサイクル毎秒 (c/s) で指示し，表 2 に示す周波数の純音を発生するものでなければならな w。

\section{表 2}

\begin{tabular}{|c|c|c|}
\hline & 気導の周波数 $\mathrm{c} / \mathrm{s}$ & 骨導の周波数 c/s \\
\hline 診 & I 形 $\left|\begin{array}{l}125,250,500,1,00 \\
2,000,4,000,8,000 \\
\text { II 形 }\end{array}\right| \begin{array}{ll}250,500,1,000, \\
2,000,4,000,8,000\end{array}$ & \begin{tabular}{|l|}
$250,500,1,000$, \\
$2,000,4,000$ \\
$250,500,1,000$, \\
$2,000,4,000,8,000$
\end{tabular} \\
\hline 選 & I 形 $\begin{array}{l}500,1,000,2,000, \\
4,000\end{array}$ & \\
\hline 侴 & II 形 $1,000 ， 4,000$ & \\
\hline
\end{tabular}

ただし診断用II形（気導・骨導）の $250 \mathrm{c} / \mathrm{s}$ ははぶ くことができる。また診断用 I 形 (気導・骨導) およ び選別用 I 形 (気導)については必要に応じて表 3 に 示す周波数を追加することができる。

\section{表 3}

\begin{tabular}{r|rrrr}
\hline $\begin{array}{c}\text { 診断用 } \\
\text { I 形 }\end{array}$ & $\begin{array}{l}\text { 気導 } \\
\text { 骨導 }\end{array}$ & $800,1,500,3,000,6,000$ & $\mathrm{c} / \mathrm{s}$ \\
選別用 & $\mid$ 気導 & $3,500,3,000,6,000,8,000 \mathrm{c} / \mathrm{s}$ \\
\hline
\end{tabular}

2.4 聴力損失の測定範囲と目盛間隔 オージオメ 一タの音の強さは基準の最小可聴值に対するデシベル (db) で指示し，その聴力損失の測定範囲抢よび聴力 損失の目盛間隔は少なくとも表 4 または表 5 亿示すも のを備えなければならない。ただし表 3 に示す周波数 を持たないときはその限りでない。
表 5 選別用

\begin{tabular}{|c|c|c|c|}
\hline & $\begin{array}{r}\text { 周波数 } \\
\mathrm{c} / \mathrm{s}\end{array}$ & 聴力損 失目 盛 \\
\hline \multirow{3}{*}{ 選別用 } & I 形 & 各周波数 & $0,5,10 \cdots \cdots(5$ 間隔 $) \cdots \cdots 60$ \\
\hline & & 1,000 & $15,20,60$ \\
\hline & & 4,000 & 20,60 \\
\hline
\end{tabular}

な扮骨導の零点は正常な聴力を有する 6 名 6 耳によ り定めたものとする。

選別用 II 形に識別導入用音を追加寸るときには， $1,000 ， 4,000 \mathrm{c} / \mathrm{s}$ と $40 \mathrm{db}$ 程度の音を用いることが望 ましい。

2.5 安全 オージオメータは電撃の危険を防止す るため接地端子を装置の外面の見やすい場所化設けな くてはならない。ただし，㨁流電源を用いたトランジ スタ式のように微小電源の場合はこの限りではない。

3. 性 能

3.1 周波数の正確さ オージオメータの発生する 純音の周波数は，診断用 I 形においてはその表示值の $\pm 3 \%$ ，診断用II 形および選別用においては土5\%の 範囲内で正確でなければならない。

3.2 気導受話器の出力音王の正確さ オージメー タの気導受話器の出力音圧注聴力損失目盛で指示され た值加 $4,000 \mathrm{c} / \mathrm{s}$ 末満の各周波数では $4 \mathrm{db}$ 以上, $4,000 \mathrm{c} / \mathrm{s}$ 以上の各周波数では $5 \mathrm{db}$ 以上異なってはな らない。

3.3 気導受話器の出力音圧の変動 オージオメー タの気導受話器の出力音圧は 4 時間にわたる連続使用 および電源電圧の定格值よりの $5 \%$ の変動に対してい ずれも $1 \mathrm{db}$ 以上変化してはならない。

3.4 聴力損失目盛間隔の誤差 聴力損失の相隣る 二つの目盛に対する出力のレベル差は目盛の間隔の 30\%以上，ただし，診断用 I 形の気導音については $20 \%$ 以異なってはならない。

3.5 気導受話器出力の倍音 気導受話器の出力に 含まれる倍音は各周波数とも全高調波ひずみ率で 5.6

断

用

\begin{tabular}{l}
\hline \\
\hline
\end{tabular}


\% (25db) より大きくてはならない。ただし, 全高調 波含有率は次式で示されるものとする。

全高調波含有率 $(\%)=\sqrt{\frac{\mathrm{P}_{2}^{2}+\mathrm{P}_{3}^{2}+\mathrm{P}_{4}^{2} \cdots \cdots}{\mathrm{P}^{2}}}$

$\mathrm{P}$ は出力音圧の実効值 $\mathrm{P}_{2} \mathrm{P}_{3} \cdots \cdots$...第 2 倍音,

第 3 倍音………...音圧の実效值とする。

3.6 純音の断続器 断続器は受話器入力電圧レベ ルを，診断用に扔いては $60 \mathrm{db}$ 以上，選別用において は30db 以上減衰できるむのであること。ただし基準 の最小可聴を与える入力電珐レベルよりも，気導にお いては15db，骨尊に㧍いては $25 \mathrm{db}$ 低いレベルまで減 衰しても，上記所要減衰值に達しない聴力損失目盛に ついてはそのレベルまで減衰できればよいものとす る。

また, そのときの減衰に要する時間およびもとの值 の土 $1 \mathrm{db}$ の值にまで復元するに要する時間柱 0.5 秒以 下でなければならない。なお, 減衰状態から必要な受 話器入力電压レベルに戻す時のオーバーシュートは, 診断用に沶いては $1 \mathrm{db}$ 以下，選別用においては $2 \mathrm{db}$ 以下でなければならない。

また, 断続器動作に伴う過渡音は正常な聴力の耳に 聴えるようなものであってはならない。

3.7 妨害音 気尊受話器の雑音入力電圧レベルは 表 3 および表 4 に与えられた $4,000 \mathrm{c} / \mathrm{s}$ の最大聴力損失 目盛における入力電圧レベルょりも診断用においては $60 \mathrm{db}$ 以上，選別用に抢いては $30 \mathrm{db}$ 以上小さくなけ ればならない。

また受話器以外からは測定の妨害になる音を出して はならない。

3.8 骨導受話器 正常な聴力の人が判断して骨導 の最小可聴值を与える状態では, 骨導受話器の出す気 導音がきこえてはならない。

3.9 絶縁打よびキョウ体リーク 交流電源で動作 するオージオメータの電源入力端子とキョウ体間の絶 縁抵抗 $500 \mathrm{~V}$ はの絶音抵抗計で $10 \mathrm{M} \Omega$ 以上でなけれ ばならない。また良好な接地とキョウ体アース端子間 に $100 \mathrm{k} \Omega$ の抵抗を接続し, 装置の電源を投入して動 作状態としたとき, 電源コンセントの極体の正負にか かわらず，100k:D の抵抗の両端の電圧は $10 \mathrm{~V}$ 以下で なければならない。

4. 試 験

4.1 試験状態 標準試験状態は温度 $20^{\circ} \mathrm{C}$, 湿度

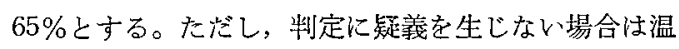
度 $5 \sim 35^{\circ} \mathrm{C}$, 湿度 $44 \sim 85 \%$ の範囲内に括いて試験して
もよい。試験は騒音, 振動, 電磁誘導および静電誘導 が少ない場所で行ないことわりがない限りオージオメ 一夕は定格電源電圧で動作させ電源投入後30分経過し てから試験を行なう。

試験に聴力目盛が指定されている場合, その目盛が ないものは，それに一番近い目盛で行なう。

4.2 気導受話器試験用カップラ 気導受話器の入 力抢よび出力に関する測定は図 6 に示すカップラを使 用し, 受話器に $400 \mathrm{~g}$ の静荷重をかけた状態で行なら。

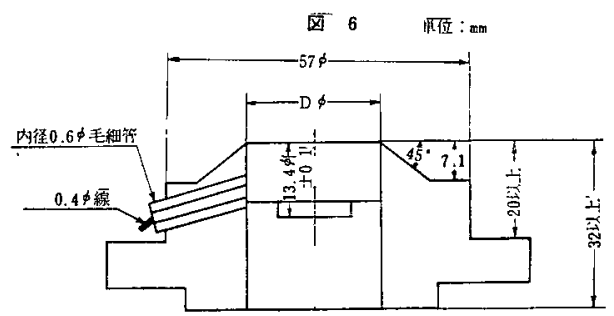

備考 1 D $\$$ は2 $23.77 \pm 0.05$ の気遒受話器試験用マ イクロホンにびったりはまる大きさ。

2 材質は非磁性金属とする。

4.3 気導受話器試験用マイクロホン 気遒受話器: 試験用マイクロホンは使用周波数で感度が校正された コンデンサマイクロホンまたはそれと同等以上のもの で4.2のカップラに適合するものとする。

4.4 聴感補正回路 測定に使用する聴感補正回路 は図 7 に示される周波数特性を有するものとする。

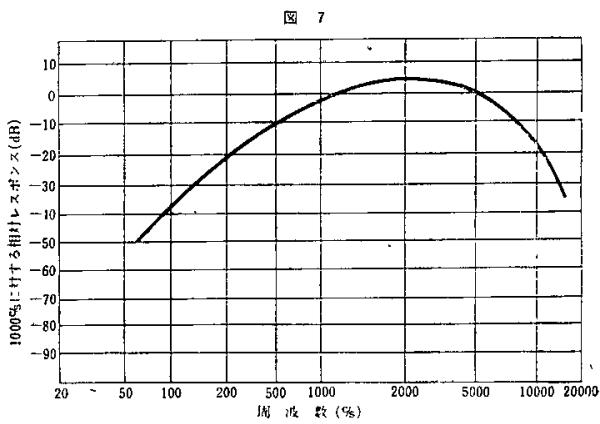

\section{5 試験項目}

\subsection{1 構造および表示検查}

4.5 .2 性能試験

(1) 純音の周波数の正確さ

(2) 気導受話器の出力音圧の正確さ

(3) 気導受話器の出力音圧の変動

(4) 聴力損失目盛の間隔

(5) 気導受話器出力の倍音

(6) 純音の断続器 
(7) 妨害音

(8) 骨導受話器

（9）絶縁およびキョウ体リーク

4.6 試験方法

4.6.1 周波数の正確さ 聴力損失目盛 $60 \mathrm{db}$ にお いて定格電源電圧㧍よびそれより土5\%変化させた電 圧で行なう。

4.6.2 気導受話器の出力音圧の正確さ 聴力損失 目盛 $60 \mathrm{db}$ については出力音圧を測定し, その他の目 盛については 4.6.4の測定と組合わせて入力電圧レベ ル測定により簡易に行ってもよい。

4.6.3 気導受話器の出力音圧の変動 聴力損失目 盛 $60 \mathrm{db}$ の出力音圧において行なら。ただし, 連続使 用中の試験は電源投入後 30 分および 4 時間後の受話器 入力電圧の测定で行なってもよい。

4. 6.4 聴力損失目盛間隔 受話器への入力電圧レ ベルの測定により行なう。図 8 にその一例を示す。

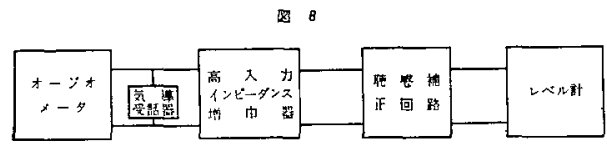

4.6 .5 気導受話器出力の倍音 最大聴力損失目盛 で行なら。

4.6.6 純音の断続器つさきように試験を行な 5 。

(1) 聴力損失目盛 $60 \mathrm{db}$ において断続器を操作して 信号を断としたときの気導受話器入力電圧レベルの減 衰量を聴感補正回路を介して測定する。

(2) 聴力損失目盛を最大目盛にとり断続器を操作し て信号を断および接として図 9 に示す時間 $t_{d}$, 復元時 間 $t_{r}$ および振れ過ぎをブラウン管オシロスコープに より調べる。ただし, 断続器の動作開始点は断続器と 連動せしめられたスイッチ接点の開閉を同一管面に表 示することにより知るものとする。

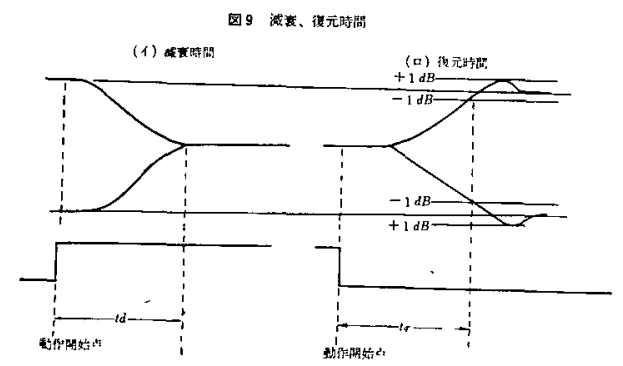

(3) 断続器操作に伴ら過渡音は正常な聴力を有する
6 名 6 耳で聴き，5名以上に聴えないこと。

4.6.7 妨害音 気導受話器の雑音入出力電圧レベ ルは，表 4 および表 5 に与えられた $4,000 \mathrm{c} / \mathrm{s}$ の最大 聴力損失目盛において, 気導受話器の入力電圧レベル を 4,000c/s の帯域消去フイルタおよび 4,000c/s の低 域フイルタを介して測定する。

4.6 .8 骨導受話器の発生する気導音 次に示す状 態において，正常な聴力を有する 6 名 6 耳以上につい て最小可聴值を測定し, その平均値の差が $5 \mathrm{db}$ より 大きいかどらか調べる。なお， $3,000 \mathrm{c} / \mathrm{s}$ 以上の音に対 してはJIS B 9904 に規定する防音用耳センを用いて छよい。

(1) 骨導受話器を, その正規の使用状態 (耳款の後 の乳様突起骨面にあてる) に保ち, 骨導の最小可聴值 を测る。

(2) 骨導受話器の振動部を指でおさえ, 正常な使用 状態と最む近い位置で頭から浮かせて保持し，気導音 を感知する最小可聴目盛を求める。

5. 表示および製品の㭔び方

5.1 表示 製品にはつぎの事項を表示するととも に，取り扱いに必要な説明書および診断用においては 骨導に対するマスキング効果を示す特性表を添付しな ければならない。

(1) 品名

（2）種類 例：選別用オージオメータI 形

(3) 製造業者および住所

(4) 製造番号

(5) 製造年月

(6) 電源電圧，周波数および消費電力

(7) その他必要な事項

5.2 製品の呼び方 製品の呼び方はつぎの例によ る。

(1) 診断用オージオメータI 形

（2）選別用オージオメータ II 形 